
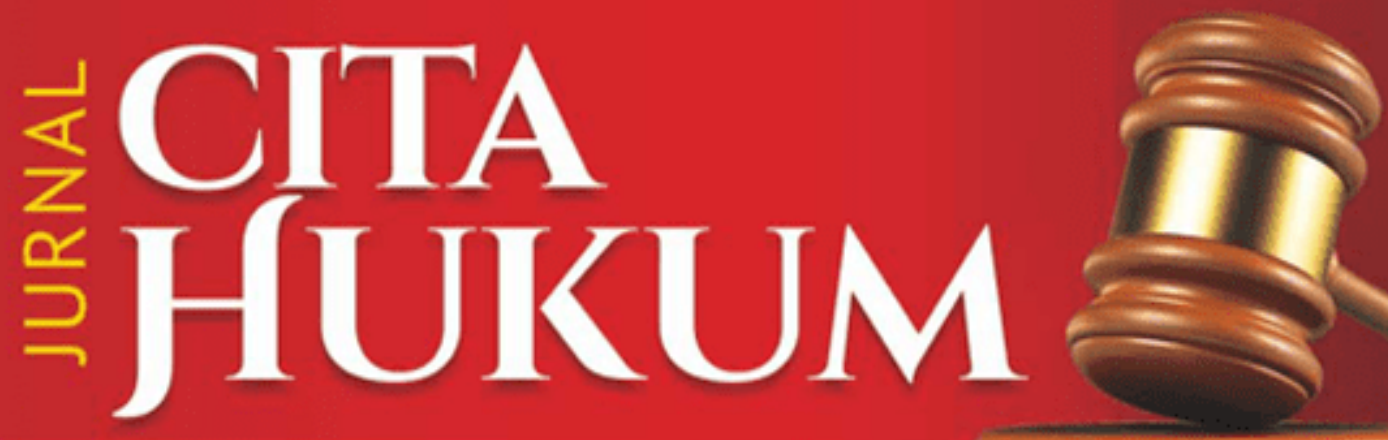

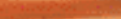

-

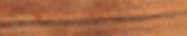

- Arah Perubahan Sistem Pemilu Dalam Undang-Undang Politik Pasca Reformasi

Masyrofah

- Hukum dan Hak Kebebasan Beragama Sodikin

- Urgensi Pemilu Presiden dan Wakil Presiden Secara Langsung Di Era Reformasi Abu Tamrin

- Rejuvinasi Sistem Checks And Balances Dalam Sistem Ketatanegaraan Di Indonesia Indra Rahmatullah

- Mekanisme Penggantian Antar Waktu (PAW) Anggota DPR dan Implikasinya Dalam Konsep Perwakilan Rakyat Rida Farida

- Kedudukan Musyawarah dan Demokrasi Di Indonesia Muhammad Hanafi

- Demokrasi dan Tata Pemerintahan Dalam Konsep Desa dan Kelurahan Setyo Nugroho

- Kewenangan Komisi Yudisial dan Dewan Perwakilan Rakyat Dalam Pengangkatan Hakim Agung Diah Savitri 


\title{
Jurnal
}

\section{CITA HUKUM}

\section{VOL. I NO. 2 DESEMBER 2013}

Diterbitkan oleh Fakultas Syariah dan Hukum Universitas Islam Negeri (UIN) Syarif Hidayatullah Jakarta bekerjasama dengan Pusat Studi Konstitusi dan Legislasi Nasional (POSKO-LEGNAS) UIN

Jakarta. Jurnal Cita Hukum mengkhususkan diri dalam pengkajian Hukum Indonesia dan terbit dua kali dalam satu tahun di setiap bulan Juni dan Desember.

\author{
Redaktur Ahli \\ Muhammad Atho Mudzhar (UIN Syarif Hidayatullah Jakarta) \\ Muhammad Amin Suma (UIN Syarif Hidayatullah Jakarta) \\ Salman Maggalatung (UIN Syarif Hidayatullah Jakarta) \\ Ahmad Hidayat Buang (University Malaya Malaysia) \\ Nadirsyah Hosen (Wollongong University Australia) \\ JM Muslimin (UIN Syarif Hidayatullah Jakarta) \\ Stephen Koos (Munchen University Germany) \\ Abdullah Sulaiman (Universitas Trisakti) \\ Jimly Asshiddiqie (Universitas Indonesia) \\ Muhammad Munir (IIU Islamabad Pakisatan) \\ Tim Lindsey (Melbourne University Australia) \\ Raihanah Azahari (University Malaya Malaysia) \\ Jaih Mubarok (UIN Sunan Gunung Djati Bandung) \\ Djawahir Hejazziey (UIN Syarif Hidayatullah Jakarta)

\section{Editor in Chief} \\ Nur Rohim Yunus \\ Managing Editor \\ Muhammad Ishar Helmi
}

\section{Editors}

Fitria

Indra Rahmatullah

Mara Sutan Rambe

\section{Asisten to The Editors}

Erwin Hikmatiar

\section{Alamat Redaksi}

Fakultas Syariah dan Hukum UIN Syarif Hidayatullah Jakarta

Jl. Ir. H. Juanda 95 Ciputat Jakarta 15412

Telp. (62-21) 74711537, Faks. (62-21) 7491821

Website: www.fsh-uinjkt.net, E-mail: jurnal.citahukum@uinjkt.ac.id

Permalink: http://journal.uinjkt.ac.id/index.php/citahukum 


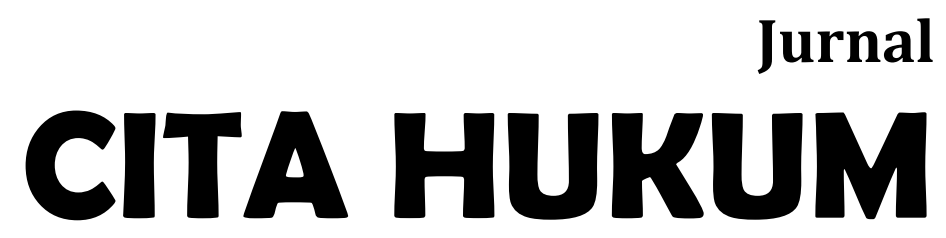

Menyambut baik kontribusi dari para ilmuwan, sarjana, profesional, dan peneliti dalam disiplin ilmu hukum untuk dipublikasi dan disebarluaskan setelah melalui mekanisme seleksi naskah, telaah mitra bebestari, dan proses penyuntingan yang ketat. 


\section{DAFTAR ISI}

165 Arah Perubahan Sistem Pemilu Dalam Undang-Undang Politik Pasca Reformasi (Usulan Perubahan Sistem Pemilu Dalam Undang-Undang Politik Pasca Reformasi)

Masyrofah

175 Hukum dan Hak Kebebasan Beragama

Sodikin

187 Urgensi Pemilu Presiden dan Wakil Presiden Secara Langsung di Era Reformasi

Abu Tamrin

195 Mekanisme Penggantian Antar Waktu (PAW) Anggota DPR dan Implikasinya Dalam Konsep Perwakilan Rakyat

Rida Farida

215 Rejuvinasi Sistem Checks And Balances Dalam Sistem Ketatanegaraan Di Indonesia

Indra Rahmatullah

227 Kedudukan Musyawarah dan Demokrasi Di Indonesia Muhammad Hanafi

247 Demokrasi dan Tata Pemerintahan Dalam Konsep Desa dan Kelurahan Setyo Nugroho

263 Kewenangan Komisi Yudisial dan Dewan Perwakilan Rakyat Dalam Pengangkatan Hakim Agung Diah Savitri 
285 Politik Hukum Larangan Pengunduran Diri Anggota Komisi Pemilihan Umum

Nur'aini

303 Penerapan Azas "Equality Before The Law" Dalam Sistem Peradilan Militer

Muhammad Ishar Helmi

317 Upaya Komisi Pemberantasan Korupsi Dalam Menangani Kasus Korupsi Gayus Halomoan P Tambunan

Siti Salimah

335 Penyesuaian Batasan Tindak Pidana Ringan dan Jumlah Denda Dalam KUHP Terhadap Perkara Tindak Pidana Pencurian; (Analisis Peraturan Mahkamah Agung Nomor 02 Tahun 2012 Tentang Penyesuaian Batasan Tindak Pidana Ringan Dan Jumlah Denda Dalam KUHP)

Muhammad Soma Karya Madari 


\title{
Mekanisme Penggantian Antar Waktu Anggota Dewan Perwakilan Rakyat dan Implikasinya Dalam Konsep Perwakilan Rakyat*
}

\author{
Rida Farida \\ Bank Rakyat Indonesia (BRI) Purwakarta \\ Jl. Purwakarta Jawa Barat \\ E-mail: Rida_hasma@gmail.com
}

\begin{abstract}
Mechanism alteration of a ruling Member of Parliament (MP) and Its Implication to People Representation Concept. Alteration of a ruling Member of Parliament functioned as mechanism of control to political party that has representative in Parliament. This regulation is obviously regulated in accordance with Act No 27 Year 2009 relating to People Representative Assembly, House of Representative and House of Regional Representative and Local House of Representative. Nowadays, alteration of ruling MP becomes an effective mean to get rid of the MP whose ideas and visions are different with the political party where they belong. On the other hand, the existence of Member of Parliament is because of the election.
\end{abstract}

Keywords: Alteration of a ruling Member of Parliament (MP), People Representation Concept

Abstrak. Mekanisme Penggantian Antar Waktu (PAW) Anggota DPR dan Implikasinya dalam Konsep Perwakilan Rakyat. Penggantian Antar Waktu (PAW) memiliki fungsi sebagai mechanism control dari partai politik yang memiliki wakilnya yang duduk sebagai anggota parlemen. Kewenangan Penggantian Antar Waktu (PAW) diatur dalam pasal 213 Undang-Undang Nomor 27 Tahun 2009 Tentang Majelis Permusyawaratan Rakyat, Dewan Perwakilan Rakyat, Dewan Perwakilan Daerah dan Dewan Perwakilan Rakyat Daerah. Dewasa ini Penggantian Antar Waktu (PAW) menjadi alat efektif untuk menggantikan anggota dewan yang berseberangan dengan kepentingan pengurus partai politik, akibatnya eksistensi anggota dewan sangat tergantung dengan selera pengurus partai politik. Disisi lain, keberadaan anggota dewan karena dipilih oleh rakyat dalam suatu pemilihan umum.

Kata Kunci: PAW; Penggantian Antar Waktu; Konsep Perwakilan Rakyat

DOI: $\underline{10.15408 / \text { jch.v1i2.2991 }}$

${ }^{*}$ Naskah diterima: 23 Juli 2013, direvisi: 27 Agustus 2013, disetujui untuk terbit: 10 Oktober 2013. 


\section{Rida Farida}

\section{Pendahuluan}

Sebuah negara yang menganut paham demokrasi paling tidak terdapat beberapa hal yang mutlak keberadaannya, yakni mengharuskan adanya pemilihan umum, rotasi atau kaderisasi kepemimpinan nasional, kekuasaan kehakiman yang independen, representasi kedaulatan rakyat melalui kelembagaan parlemen yang kuat dan mandiri, penghormatan dan jaminan hak asasi manusia, serta konstitusi yang memberikan jaminan hal-hal tersebut berjalan. ${ }^{1}$

Indonesia merupakan negara berkedaulatan. Kedaulatan tertinggi berada di tangan rakyat dan dilakukan sepenuhnya oleh Majelis Permusyawaratan Rakyat. Begitulah bunyi Pasal 1 ayat (2) Undang-Undang Dasar 1945. Dengan ketentuan tersebut, menunjukkan bahwa demokrasi di Indonesia adalah demokrasi tidak langsung dan pemerintah Indonesia menganut paham demokrasi perwakilan. Seperti bunyi sila keempat Pancasila, "Kerakyatan yang dipimpin oleh hikmat kebijaksanaan dalam permusyawaratan/perwakilan".

Hal-hal yang mutlak keberadaannya itu merupakan penjelmaan dari kedaulatan rakyat yang berjalan bersamaan dengan paham nomokrasi. Dikatakan berjalan bersamaan dengan prinsip nomokrasi karena demokrasi yang berarti pemerintahan rakyat tentunya didasari pada partisipasi rakyat dalam pemerintahan. Di negara demokrasi dimana hak-hak individual rakyat sangat dihargai dan dijamin kebebasannya termasuk dalam hal ini menggunakan hak politiknya secara aktif maupun pasif dalam pemerintahan haruslah diatur dengan hukum. $^{2}$

Amandemen Undang-Undang Dasar 1945 membawa perubahan besar di bidang sosial, politik dan hukum di Indonesia. Perubahan itu berimplikasi pada perkembangan pelaksanaan demokrasi di Indonesia yang ditandai dengan adanya pemilihan umum langsung untuk memilih Presiden dan Wakil Presiden, pemilihan umum langsung untuk memilih anggota legislatif, atau yang terbaru adalah keberadaan calon independen dalam pemilihan umum kepala daerah dan wakil kepala daerah.

Negara demokrasi tentunya membenarkan keberadaan Partai Politik sebagai pilar dari demokrasi atau pelaksanaan kedaulatan rakyat. Partai politik pada pokoknya memiliki kedudukan (status) dan peranan (role) yang sentral dan penting dalam setiap sistem demokrasi karena memainkan peran yang penting sebagai penghubung antara pemerintahan negara (the state) dengan warga negaranya (the citizens). ${ }^{3}$

Partai politik adalah pilar demokrasi. Jika pilar ini tidak lagi dipercaya oleh rakyat, maka hal itu merupakan ancaman serius terhadap keberlangsungan 1992, h. 60 .

${ }^{1}$ Miriam Budiardjo, Dasar-dasar Ilmu Politik, Cetakan ke-14, Gramedia Pustaka Utama, Jakarta,

2 Putusan Nomor 22-24/PUU-VI/2008 Tentang Pengujian Undang-Undang Nomor 10 Tahun 2008 tentang Pemilihan Umum Anggota Dewan Perwakilan Rakyat, Dewan Perwakilan Daerah, dan Dewan Perwakilan Rakyat Daerah.

${ }^{3}$ Jimly Asshiddiqie, Pokok-Pokok Hukum Tata Negara Indonesia Pasca Reformasi, (Jakarta, BIP, 2007), h. 710.

196 - Jurnal Cita Hukum. Vol. I No. 2 Desember 2013. 
demokrasi di Indonesia. Dengan demikian, mengembalikan partai politik kepada jalur yang benar dalam arus demokratisasi di Indonesia menjadi tanggung jawab kita semua. Partai politik juga hanya bukan sekedar organisasi tempat berkumpulnya politisi, tetapi juga dapat menjalankan fungsinya bagi kepentingan masyarakat. Dengan demikian dalam sistem demokrasi, partai memegang peranan yang sangat penting.

Pemilihan umum merupakan salah satu cara untuk menentukan wakil rakyat yang akan duduk dalam badan perwakilan rakyat. Menjadi perwakilan politik dalam kerangka kerja suatu sistem demokrasi membawa beban dan tanggung jawab serta konsekuensi politik yang relatif besar. Karena itu, disamping jeratan hukum karena pelanggaran terhadap peraturan perundang-undangan yang dapat dibuktikan secara materi di pengadilan umum, anggota dewan menghadapi tantangan untuk digugat secara politis baik oleh partai politik induknya maupun konstituen dan masyarakat pada umumnya. ${ }^{4}$ Kenyataannya, Indonesia cenderung menganut model diversifikasi dimana anggota DPR merupakan wakil dari partai politik. Hal ini berarti anggota DPR harus mewakili kepentingan partai politik dan menyuarakan suara partai politik. Adanya sistem Penggantian Antar Waktu (PAW) yang digunakan oleh partai politik terhadap anggota DPR yang berasal dari partai politik yang bersangkutan memperkuat hal tersebut.

Saat ini kewenangan Penggantian Antar Waktu (PAW) diatur dalam pasal 213 Undang-Undang Nomor 27 Tahun 2009 Tentang Majelis Permusyawaratan Rakyat, Dewan Perwakilan Rakyat, Dewan Perwakilan Daerah dan Dewan Perwakilan Rakyat Daerah.

Penggantian Antar Waktu (PAW) sempat ditiadakan berdasarkan ketentuan Undang-Undang Nomor 4 Tahun 1999 tentang Susunan dan Kedudukan Majelis Permusyawaratan Rakyat, Dewan Perwakilan Rakyat, dan Dewan Perwakilan Rakyat Daerah. Penghapusan Penggantian Antar Waktu (PAW) tersebut sebagai imbas dalam rangka untuk penguatan parlemen. Namun, hal ini pun menjadi polemik, karena sejumlah anggota dewan yang berbuat tidak pantas, misalnya pindah partai politik, melakukan perbuatan amoral, atau melakukan pelanggaran kode etik tidak mendapatkan sanksi tegas. Sedangkan tuntutan masyarakat menginginkan anggota dewan yang accountable, baik kinerja politiknya maupun etika perilakunya. Oleh karena itu Penggantian Antar Waktu (PAW) dimunculkan kembali dengan diatur dalam Undang-Undang Nomor 27 Tahun 2009 Tentang Majelis Permusyawaratan Rakyat, Dewan Perwakilan Rakyat, Dewan Perwakilan Daerah, dan Dewan Perwakilan Rakyat Daerah dan Undang-Undang Nomor 2 Tahun 2008 Tentang Partai Politik. Tetapi dalam perjalanannya, wewenang Penggantian Antar Waktu (PAW) ini pun disalahartikan oleh petinggi-petinggi partai. Anggota dewan yang bersebrangan pendapat dengan partai mendapat sanksi dan diberhentikan melalui mekanisme Penggantian Antar Waktu (PAW). Padahal anggota dewan tersebut menyuarakan aspirasi rakyat.

\footnotetext{
4 Sebastian Salang, Menghindari Jeratan Hukum Bagi Anggota Dewan, (Jakarta: PT. Penebar Swadaya, 2009), h. 269.
} 


\section{Rida Farida}

\section{Penggantian Antar Waktu (PAW)}

Dalam bahasa sehari-hari, Penggantian Antar Waktu (PAW) anggota DPR diasosiasikan sebagai recall. Secara etimologis, kata recall dalam bahasa Inggris mengandung beberapa pengertian. Setidaknya menurut Peter Salim (dalam The Contemporary English-Indonesia), yakni mengingat, memanggil kembali, menarik kembali atau membatalkan. Penggantian Antar Waktu (PAW) diartikan sebagai proses penarikan kembali atau penggantian kembali anggota DPR oleh induk organisasinya yang tentu saja partai politik. ${ }^{5}$

Recall yang terdiri kata "re" yang artinya kembali, dan "call" yang artinya panggil atau memanggil. Jika kata ini disatukan maka kata recall ini akan berarti dipanggil atau memanggil kembali. Kata recall ini merupakan suatu istilah yang ditemukan dalam kamus ilmu politik yang digunakan untuk menerangkan suatu peristiwa penarikan seorang atau beberapa orang wakil yang duduk dalam lembaga perwakilan (melalui proses pemilu), oleh rakyat pemilihnya. Jadi dalam konteks ini recall merupakan suatu hak yang dimiliki pemilih terhadap orang yang dipilihnya. ${ }^{6}$

Penggantian Antar Waktu (PAW) atau recall adalah istilah pinjaman yang belum ada padanya di Indonesia. Pengertian recall di Indonesia berbeda dengan pengertian recall di Amerika Serikat. Di Amerika serikat istilah recall, lengkapnya Recall Election yang digunakan untuk menyatakan hak rakyat pemilih (konstituen) untuk melengserkan wakil rakyat sebelum masa jabatannya berakhir. ${ }^{7}$ Penggantian Antar Waktu (PAW) juga diartikan sebagai proses penarikan kembali anggota lembaga perwakilan rakyat untuk diberhentikan dan digantikan dengan anggota lainnya sebelum berakhir masa jabatan anggota yang ditarik tersebut. ${ }^{8}$ Penggantian Antar Waktu (PAW) adalah suatu proses penarikan kembali atau pergantian DPR oleh induk organisasinya. Hak Penggantian Antar Waktu (PAW) diatur dalam Pasal 213 Undang-Undang Nomor 27 Tahun 2009 tentang MPR, DPR, DPD dan DPRD. Penggantian Antar Waktu (PAW) berfungsi sebagai mechanism control dari partai politik yang memiliki wakilnya yang duduk sebagai anggota parlemen.

Hak Penggantian Antar Waktu (PAW) didefinisikan oleh sejumlah ahli, salah satunya oleh Mh. Isnaeni mengatakan: Hak Penggantian Antar Waktu (PAW) pada umumnya merupakan suatu 'pedang Democles' bagi tiap-tiap anggota DPR. Dengan adanya hak recall maka anggota DPR akan lebih banyak menunggu petunjuk dan pedoman pimpinan fraksinya dari pada ber-oto-aktivitas. Melakukan oto-aktivitas yang tinggi tanpa restu pimpinan fraksi kemungkinan besar melakukan kesalahan fatal yang dapat berakibat recalling. Karena itu untuk

\footnotetext{
${ }^{5}$ BN. Marbun, Kamus Hukum Indonesia, (Jakarta: Pustaka Sinar Harapan, 2006), h. 417.

6 Haris Munandar, Pembangunan Politik, Situasi Global dan Hak Asasi Manusia, (Jakarta: Gramedia, 1994), h. 128.

${ }^{7}$ Ananda B. Kusuma, Jurnal Konstitusi Volume 3 Nomor 4 Tentang Recall, (Jakarta: MK RI, 2006), h. 156 .

${ }^{8}$ Mahfud MD, Politik Hukum Di Indonesia, (Jakarta: Rajawali Pers, 2009), h. 318.
}

198 - Jurnal Cita Hukum. Vol. I No. 2 Desember 2013. 
keamanan keanggotaannya lebih baik menunggu apa yang diinstruksikan oleh pimpinan fraksinya. ${ }^{9}$

Moh. Hatta juga pernah mengatakan: Hak Penggantian Antar Waktu (PAW) bertentangan dengan demokrasi apalagi dengan demokrasi Pancasila. Pimpinan partai tidak berhak membatalkan anggotanya sebagai hasil dari pemilu. Rupanya dalam kenyataannya pimpinan partai merasa lebih berkuasa dari rakyat pemilihnya. Kalau demikian adanya ia menganjurkan agar pemilu ditiadakan saja. Pada dasarnya hak PAW ini hanya ada pada negara komunis dan fasis yang bersifat otoriter. ${ }^{10}$ Adapun Moh. Mahfud MD, mengartikan Penggantian Antar Waktu (PAW) adalah hak untuk mengganti anggota lembaga permusyawaratan/ perwakilan dari kedudukannya sehingga tidak lagi memiliki status keanggotaan di lembaga tersebut. ${ }^{11}$

Menurut penulis, Penggantian Antar Waktu (PAW) juga dapat diartikan hak suatu organisasi sosial politik yang mempunyai wakil di MPR, DPR dan DPRD untuk mengganti wakil-wakilnya di lembaga perwakilan sebelum yang bersangkutan habis keanggotaannya, dengan terlebih dahulu bermusyawarah dengan pimpinan lembaga perwakilan tersebut dengan alasan tertentu.

\section{Sejarah dan Perkembangan Penggantian Antar Waktu (PAW)}

Penggantian Antar Waktu (PAW) berkembang sejak tahun 1903 di California, ada 117 kali percobaan untuk melengserkan para Anggota legislatif. Ada 7 kali yang sampai pada pemungutan suara pemilih, tetapi tidak ada satupun yang berhasil. Pada umumnya warga negara Amerika Serikat berpendapat bahwa masa jabatan anggota legislatif yang hanya dua tahun itu tidak cukup untuk menilai keberhasilan seseorang. Bila seorang representatif di anggap tidak berhasil maka dia tidak akan dipilih kembali. Penggantian Antar Waktu (PAW) untuk eksekutif hanya berhasil melengserkan Gubernur North Dakota, Lynn J. Frazier pada tahun 1921 dan Gubernur California Gray Davis pada tahun 2003. ${ }^{12}$

Di Amerika Serikat, prosedur Penggantian Antar Waktu (PAW) dimulai dari inisiatif rakyat pemilih yang mengajukan petisi kepada para anggota Badan Perwakilan. Bila Badan Perwakilan Rakyat menyetujui petisi pemilih (konstituen), maka diadakan pemungutan suara yang akan menentukan apakah wakil rakyat terkait akan lengser atau tetap di jabatannya. Penggantian Antar Waktu (PAW) adalah hak dari konstituen, bukan hak dari wakil rakyat (representatif). ${ }^{13}$

\footnotetext{
${ }^{9}$ Mh. Isnaeni, MPR-DPR sebagai Wahana Mewujudkan Demokrasi Pancasila, (Jakarta: Yayasan Idayu, 1982), h. 57-58.

10 Deliar Noer, Mohammad Hatta Suatu Biografi Politik, (Jakarta: LP3ES, 1989), h.305-306

11 Moh. Mahfud MD, Perkembangan Politik Hukum, Studi tentang Pengaruh Konfigurasi Politik terhadap Produk Hukum di Indonesia, (Yogyakarta: FH UGM Press, 1993), h. 324.

12 http://www.hukumonline.com/Mempertanyakan Hegemoni Penggantian Antar Waktu (PAW) Anggota DPR di Tangan Partai Politik, diaskes pada 19 Desember 2011.

${ }^{13}$ Ananda B. Kusuma, Jurnal Konstitusi Volume 3 Nomor 4 Tentang Recall, (Jakarta: MK RI, 2006), h. 156.
} 


\section{Rida Farida}

Jika menyimak sejarah konstitusi Indonesia maka akan terlihat bahwa para penyusun konstitusi (framers of the constitution) menganut teori "Representative sebagai Trustee", bukan "Representative sebagai Delegate/ Messenger Boy". Hal itu tercermin di Pasal 72 UUD Tahun 1950 yang menyatakan bahwa "Anggotaanggota DPR mengeluarkan suaranya sebagai orang yang bebas, menurut perasaan dan kehormatan batinnya, tidak atas perintah dan kewajiban berembuk dahulu dengan orang yang menunjuknya sebagai anggota". ${ }^{14}$

Pada dasarnya wacana mengenai Penggantian Antar Waktu (PAW) terkait erat dengan partai politik (parpol) baik struktur organisasi maupun fungsinya. Hak Penggantian Antar Waktu (PAW) berada di tangan pengurus parpol darimana anggota legislatif bersangkutan berasal. Dengan demikian peranan pengurus parpol dalam penggunaan hak Penggantian Antar Waktu (PAW) sangat menentukan. ${ }^{15}$

Dewasa ini Penggantian Antar Waktu (PAW) menjadi alat efektif untuk menyingkirkan anggota dewan yang berseberangan dengan kepentingan pengurus partai politik, akibatnya eksistensi anggota dewan sangat tergantung dengan selera pengurus partai politik, sehingga menggeser orientasi anggota dewan menjadi penyalur kepentingan pengurus partai politik, padahal keberadaan anggota dewan karena dipilih oleh rakyat dalam suatu pemilihan umum yang bersifat langsung, bebas, jujur dan adil.

Penggantian Antar Waktu (PAW) dihidupkan kembali dan bahkan mendapat payung konstitusional. Dalam pengaturan perundang-undangan yang lahir kemudian, seperti Undang-Undang Nomor 27 Tahun 2009 tentang MPR, DPR, DPD dan DPRD, hak Penggantian Antar Waktu (PAW) partai politik semakin dipertegas. Meskipun Undang-Undang baru ini dianggap telah melakukan perubahan mendasar terhadap DPR sebagai penyalur aspirasi rakyat, ternyata Penggantian Antar Waktu (PAW) masih tetap dikenal.

Hak Penggantian Antar Waktu (PAW) dapat dilakukan partai politik terhadap para anggotanya yang duduk sebagai anggota parlemen, baik di tingkat pusat maupun di tingkat daerah. Penggantian Antar Waktu (PAW) sendiri tidak lepas dari eksistensi partai politik. Keberadaan partai politik merupakan salah satu dari bentuk perlembagaan sebagai wujud ekspresi ide, pikiran, pandangan, dan keyakinan bebas dalam masyarakat demokratis. Karena itu, keberadaan partai politik berkaitan erat dengan prinsip-prinsip kemerdekaan berpendapat (freedom of expression), berorganisasi (freedom of association), dan berkumpul (freedom of assembly). ${ }^{16}$

${ }_{14}$ Konstitusi RIS 1949, di Pasal 90, menyatakan bahwa "Angota-anggota Senat mengeluarkan suaranya sebagai orang yang bebas, menurut perasaan dan kehormatan batinnya, tidak atas perintah atau dengan kewajiban berembuk dahulu dengan mereka yang menunjuknya sebagai anggota." Pasal 38 Basic Law for the Federal Republic of Germany menyatakan, "The deputies of the German Bundestag are elected in universal, direct, free, equal and secret election. They are representatives of the whole people, are not bound by orders and instructions and are subject only to their conscience".

${ }^{15}$ Indra Samega, Menata Negara, Usulan LIPI tentang RUU Politik, (Bandung: Mizan, 1998), h. 59.

${ }^{16}$ www.hukumonline.com, Mempertanyakan Hegemoni recall Anggota DPR di Tangan Partai Politik, diakses pada 19 Desember 2011. 
Prinsip-prinsip diatas diakui dan dijamin oleh Undang-Undang Dasar Negara Republik Indonesia tahun 1945 secara eksplisit diatur dalam Pasal 28E ayat (3) yang berbunyi, "Setiap orang berhak atas kebebasan berserikat,berkumpul, dan mengeluarkan pendapat". Praktek Penggantian Antar Waktu (PAW) yang dilaksanakan oleh partai-partai politik pada masa orde baru yang diintervensi oleh muatan politis, kembali terjadi ketika PKB melakukan Penggantian Antar Waktu (PAW) dua kadernya, yakni Lily Wahid dan Effendy Choirie, akibat keduanya berseberangan pandangan dengan parpolnya ketika voting terbuka mengenai hak angket mafia pajak.

\section{Penggantian Antar Waktu (PAW) di Masa Orde Baru}

Perkembangan Penggantian Antar Waktu (PAW) di Indonesia secara historis diatur dalam Undang-Undang Nomor 10 Tahun 1966 dimana terkandung maksud politis yang sangat kental dalam mengimplementasikan Undang-Undang ini, yakni untuk menyingkirkan anggota-anggota Parlemen yang masih setia kepada Soekarno. Secara filosofis, regulasi ini jelas menabrak Pancasila dan UndangUndang Dasar 1945 yang berkedudukkan sebagai nilai positif yang tertinggi. Ketika masa orde baru berakhir, dan masuk pada masa reformasi, hak Penggantian Antar Waktu (PAW) kembali diorbitkan pada Undang-Undang Nomor 23 Tahun 2009.17

Keberadaan hak Penggantian Antar Waktu (PAW) di masa Orde Baru diatur dalam Pasal 15 Undang-Undang Nomor 10 Tahun 1966 yang menyatakam bahwa anggota MPRS/DPR-GR dapat diganti menurut ketentuan sebagai berikut: ${ }^{18}$ a). Anggota dari calon Golongan Politik dapat diganti atas permintaan partai yang bersangkutan; b). Anggota Golongan Karya yang organisasinya berafiliasi dengan satu partai politik dapat diganti atas permintaan organisasi atau instansi yang bersangkutan; c). Anggota Golongan Karya yang organisasinya tidak berafiliasi dengan suatu partai politik dapat diganti atas permintaan organisasi atau instansi yang bersangkutan.

Selama berlangsungnya pemerintahan Orde Baru, sejumlah partai politik yang pernah melakukan Penggantian Antar Waktu (PAW) terhadap anggota partainya di parlemen antara lain: Pertama, Partai Persatuan Pembangunan (PPP). Di bawah kepemimpinan H.J. Naro pernah megusulkan Penggantian Antar Waktu (PAW) untuk Syaifudin Harahap, Tamim Achda, Murtadho Makmur, Rusli Halil, Chalid Mawardi, MA. Ganni Darussamin AS, dan Ruhani Abdul Hakim (semuanya anggota DPR periode 1982-1987). Namun usulan Penggantian Antar Waktu (PAW) untuk mereka yang diusulkan sejak Desember 1984 hingga Maret 1985 ditanggapi dingin oleh pimpinan DPR waktu itu (Amir Machmud) dan ternyata usul Penggantian Antar Waktu (PAW) itu tidak diteruskan oleh pimpinan

17 Bintan R. Siragih, Peranan DPR-GR Periode 1965-1971 dalam Menegaskan Kehidupan Ketenagakerjaan yang Konstitusional Berdasarkan UUD 1945, Disertasi, Fakultas Universitas Padjajaran, Bandung, 1992), h.324

${ }^{18}$ Lihat Pasal 15 UU No. 10 Tahun 1966 tentang Kedudukan Majelis Permusyawaratan Sementara dan Dewan Perwakilan Rakyat Gotong Royong Menjenlang Pemilihan Umum. 


\section{Rida Farida}

DPR kepada Presiden. ${ }^{19}$ Kemudian pada tahun 1955 Sri Bintang Pamungkas diPAW oleh Fraksi Persatuan Pembangunan (DPR periode 1992-1998) dengan alasan melakukan 'dosa politik' (melanggar tata tertib partai). ${ }^{20}$

Kedua, Partai Demokrasi Indonesia (PDI). Di bawah kepemimpinan Soenawar Soekawati mengusulkan Penggantian Antar Waktu (PAW) untuk Usep Ranawidjaja, Abdul Madjid, Ny. D. Walandow, Soelolo, Santosa Donoseputro, TAM. Simatupang, dan Abdullah Eteng (semuanya anggota DPR periode 19771982). Kemudian ketika PDI dipimpin Soerjadi pernah diusulkan recalling untuk Marsoesi, Dudy Singadilaga, Nurhasan, Polensuka, Kemas Fachrudin, Edi Junaedi, Suparman, Jaffar dan Thalib Ali (semua anggota DPR periode 1982-1987). ${ }^{21}$

Ketiga, Golongan Karya (Golkar). Penggantian Antar Waktu (PAW) ditubuh Golkar pertama menimpa Rahman Tolleng (nggota DPR periode 1971-1977) karena dianggap terlibat kasus Malari 15 Januari 1974. Penggantian Antar Waktu (PAW) kedua terjadi pada Bambang Warih (anggota DPR periode 1992-1998) yang dipandang melakukan 'dosa politik' (melanggar tata tertib partai). ${ }^{22}$

Keempat, Fraksi ABRI. Pernah me-recall anggotanya di MPR, yakni Brigjen Rukmini, Brigjen Samsudin dan Brigjen J. Sembiring, karena mengkritisi pembelian kapal perang bekas milik pemerintahan Jerman.

\section{Penggantian Antar Waktu (PAW) di Masa Reformasi}

Setelah Orde Baru tumbang digantikan Orde Reformasi, mekanisme Penggantian Antar Waktu (PAW) oleh partai politik yang selama Orde Baru efektif digunakan oleh partai politik untuk menyingkirkan 'lawan politik' di tubuh partainya, tidak lagi diatur dalam Undang-Undang Nomor 4 Tahun 1999 tentang Susunan dan Kedudukan MPR, DPR dan DPRD. Di Pasal 5 ayat (1) ditegaskan anggota MPR berhenti antar waktu sebagai anggota karena: $\left.{ }^{23} \mathrm{a}\right)$. Meninggal dunia; b). Permintaan sendiri secara tertulis kepada Pimpinan MPR; c). Bertempat tinggal di luar wilayah Negara Kesatuan Republik Indonesia; d). Berhenti sebagai anggota DPR; e). Tidak lagi memenuhi syarat-syarat sebagaimana yang dimaksud Pasal 3 ayat (1) berdasarkan keterangan yang berwajib; f). Dinyatakan melanggar sumpah/janji sebagai wakil-wakil rakyat dengan keputusan MPR; g). Terkena larangan penangkapan jabatan sebagaimana yang dimaksud Pasal 41 ayat (1).

Akan tetapi pengaturan Penggantian Antar Waktu (PAW) kembali muncul dalam Undang-Undang Nomor 22 Tahun 2003 tentang Susunan dan Kedudukan MPR, DPR dan DPRD. Di Pasal 85 ayat (1) ditegaskan anggota DPR berhenti antar waktu karena; a). Meninggal dunia; b). Mengundurkan diri sebagai anggota atas permintaan sendiri secara tertulis; dan c). Diusulkan oleh partai politik yang bersangkutan.

19 Tiras, 16 Februari 1995, h. 19.

20 Sri Bintang Pamungkas, Saya Musuh Politik Soeharto, (Jakarta: Pijar Indonesia, 1994), h. 79.

21 Tiras, 16 Februari 1995, h. 29.

22 Forum Keadilan, 2 Maret 1995.

${ }^{23}$ Lihat Pasal 5 ayat (1) UU No.4 Tahun 1999 tentang Susunan dan Kedudukan MPR, DPR dan DPRD.

202 - Jurnal Cita Hukum. Vol. I No. 2 Desember 2013. 
Adapun alasan anggota DPR yang diberhentikan antar waktu dalam ayat (2) karena: 24 a). Tidak dapat melaksanakan tugas secara berkelanjutan atau berhalangan tetap sebagai anggota DPR; $b$ ). Tidak lagi memenuhi syarat-syarat calon anggota DPR sebagaimana dimaksud dalam UU tentang Pemilu; c). Melanggar sumpah/janji, kode etik DPR, dan/atau tidak melaksanakan kewajiban sebagai anggota DPR berdasarkan hasil pemeriksaan badan kehormatan DPR; d). Melanggar peraturan larangan rangkap jabatan sebagaimana diatur dalam ketentuan peraturan perundang-undangan; dan e). Dinyatakan bersalah berdasarkan putusan pengadilan yang telah mempunyai kekuatan hukum tetap karena melanggar tindak pidana dengan ancaman pidana serendah-rendahnya lima tahun penjara.

Pemberhentian anggota DPR yang telah memenuhi ketentuan pada ayat (1) huruf $a$, b dan c serta ayat (2) huruf $d$ dan e langsung disampaikan oleh Pimpinan DPR kepada Presiden untuk diresmikan. Pemberhentian anggota DPR yang telah yang telah memnuhi ketentuan pada ayat (2) huruf a, b dan c setelah dilakukan penyelidikan, verifikasi dan pengambilan keputusan oleh badan kehormatan DPR atas pengaduan Pimpinan DPR, masyarakat dan/atau pemilih. Tata cara pengaduan, pembelaan dan pengambilan keputusan oleh badan kehormatan DPR diatur dalam Peraturan Tata Tertib DPR.

Di dalam Undang-Undang Nomor 31 Tahun 2002 tentang Partai Politik ditentukan dalam Pasal 12 bahwa anggota partai politik yang menjadi anggota lembaga perwakilan rakyat apabila: ${ }^{25}$ a). Menyatakan mengundurkan diri dari keanggotaan parpol yang bersangkutan atau menyatakan menjadi anggota parpol lain; b). Diberhentikan dari keanggotaan parpol bersangkutan karena melanggar AD dan ART; atau c). Melakukan pelanggaran peraturan perundang-undangan yang menyebabkan yang bersangkutan diberhentikan.

Ditambah lagi ketentuan dalam Pasal 11 ayat (3) menyatakan bahwa anggota parpol wajib memenuhi AD dan ART serta berkewajiban untuk berpartisipasi dalam kegiatan parpol.

UUD 1945 yang telah mengalami perubahan empat kali, juga mengatur masalah pemberhentian anggota DPR di Pasal 22B yang menyatakan "Anggota DPR dapat diberhentikan dari jabatannya, yang syarat-syarat dan tata caranya diatur dalam Undang-Undang". Pada periode 2004-2009, salah satu anggota Fraksi Partai Amanat Nasional Djoko Edhi Soetjipto Abdurahman dikenakan Penggantian Antar Waktu (PAW) dari DPR karena tindakannya ikut studi banding ke luar negeri dipandang bertentangan dengan garis kebijakan partai. Akibat pemecatannya tersebut, Djoko Edhi mengajikan judicial review Undang-Undang Nomor 22 Tahun 2003 tentang Susunan dan Kedudukan MPR, DPR dan DPRD dan Undang-Undang Nomor 31 Tahun 2002 tentang Partai Politik ke Mahkamah

${ }^{24}$ Lihat Pasal 85 ayat (2) UU No. 22 Tahun 2003 tentang Susunan dan Kedudukan MPR, DPR dan DPRD.

${ }^{25}$ Lihat Pasal 12 UU No. 31 Tahun 2002 tentang Partai Politik.

Fakultas Syariah dan Hukum UIN Syarif Hidayatullah Jakarta - 203 


\section{Rida Farida}

Konstitusi. Akan tetapi permohonan tersebut ditolak untuk seluruhnya karena dalil-dalil pemohon dipandang tidak beralasan. ${ }^{26}$

\section{Landasan Hukum Penggantian Antar Waktu (PAW)}

Hukum yang baik adalah hukum yang diterima oleh rakyat karena ia mencerminkan kesadaran hukumnya. ${ }^{27}$ Maka untuk melaksanakan hukum yang dapat diterima oleh masyarakat diperlukan pejabat-pejabat atau penguasa yang mengerti akan pentingnya keadilan, sehingga fungsi dari hukum itu sendiri dapat terealisasi dengan baik.

Muchtar Kusumaatmadja, seperti dikutip oleh Soerjono Soekanto, mengajukan pula beberapa fungsi hukum sebagai berikut:

“Di Indonesia fungsi hukum di dalam pembangunan sebagai sarana pembangunan masyarakat. Hal ini didasarkan pada anggapan bahwa ketertiban dalam pembangunan merupakan suatu yang dianggap penting dan sangat diperlukan. Disamping itu, hukum sebagai tata kaedah dapat berfungsi untuk menyalurkan arah kegiatan warga masyarakat ke tujuan yang dikehendaki oleh perubahan tersebut. Sudah tentu bahwa fungsi hukum di atas seharusnya dilakukan, di samping fungsi hukum sebagai sistem pengendalian sosial." 28

Secara konstitusional hak Pergantian Antar Waktu (PAW) diatur dalam Pasal 22B UUD 1945 yang menyatakan bahwa anggota DPR dapat diberhentikan dari jabatannya, dengan syarat-syarat dan tata cara yang diatur dalam UndangUndang. Landasan konstitusional ini termaktub dalam amandemen kedua UUD 1945. Dari landasan ini dapat dirangkum bahwa Penggantian Antar Waktu (PAW) dapat diterapkan kepada anggota Dewan.

Mulai tahun 2009 Pengaturan Penggantian Antar Waktu (PAW) kembali muncul dalam Pasal 213 ayat (1) yang menentukan bahwa anggota DPR berhenti antar waktu karena: a. meninggal dunia; b. mengundurkan diri; atau c. diberhentikan. Kemudian pada ayat (2) ditegaskan Anggota DPR diberhentikan Antar Waktu sebagaimana dimaksud pada ayat (1) huruf c, apabila: ${ }^{29}$ a). tidak dapat melaksanakan tugas secara berkelanjutan atau berhalangan tetap sebagai anggota DPR selama 3 (tiga) bulan berturut-turut tanpa keterangan apa pun; b). melanggar sumpah/janji jabatan dan kode etik DPR; c). dinyatakan bersalah berdasarkan putusan pengadilan yang telah memperoleh kekuatan hukum tetap karena melakukan tindak pidana yang diancam dengan pidana penjara 5 (lima) tahun atau lebih; d). tidak menghadiri rapat paripurna dan/atau rapat alat kelengkapan DPR yang menjadi tugas dan kewajibannya sebanyak 6 (enam) kali berturut-turut tanpa alasan yang sah; e). diusulkan oleh partai politiknya sesuai dengan peraturan perundang-undangan; f). tidak lagi memenuhi syarat sebagai calon anggota DPR sesuai dengan ketentuan peraturan perundang-undangan mengenai pemilihan umum anggota DPR, DPD, dan DPRD; g). melanggar

\footnotetext{
${ }^{26}$ Lihat Putusan MK RI No.008/PUU-IV/2006.

${ }^{27}$ Moh. Kusnardi, Ilmu Negara, (Jakarta: Gaya Media Pratama, 2000), h. 135.

28 Soerjono Soekanto, Kesadaran Hukum dan Kepatuhan Hukum, (Jakarta: Rajawali, 1982), h. 9.

${ }^{29}$ Lihat Pasal 213 ayat (2) UU No. 27 Tahun 2009 tentang MPR, DPR, DPD dan DPRD.
} 
ketentuan larangan sebagaimana diatur dalam Undang-Undang ini; $\mathrm{h}$ ). diberhentikan sebagai anggota partai politik sesuai dengan ketentuan peraturan perundang-undangan; atau i). menjadi anggota partai politik lain.

Di dalam Pasal 214 ditentukan bahwa pemberhentian anggota DPR sebagaimana dimaksud dalam Pasal 214 ditentukan bahwa pemberhentian anggota DPR sebagaimana dimaksud dalam Pasal 213 ayat (1) huruf a dan b serta pada ayat (2) huruf c, e, h dan i diusulkan oleh pimpinan parpol kepada pimpinan DPR dengan tembusan kepada Presiden. Paling lama 7 (tujuh) hari sejak diterimanya usulan pemberhentian sebagaimana dimaksud pada ayat (1), pimpina DPR menyampaikan usul pemberhentian anggota DPR kepada Presiden untuk memperoleh peresmian pemberhentian. Presiden meresmikan pemberhentian sebagaimana dimaksud pada ayat (2) paling lama 14 (empat belas) hari sejak diterimanya usul pemberhentian anggota DPR dari pimpinan DPR. Klausula "diusulkan oleh pimpinan parpol kepada Presiden", dapat dimaknai keputusan Penggantian Antar Waktu (PAW) terhadap anggota DPR barulah 'usul' dan keputusannya terserah pimpinan DPR dan Presiden.

Pimpinan DPR, dilihat dari sudut hukum adalah pelaksana tugas-tugas koordinatif dan protokoler. Pimpinan DPR bukanlah 'atasan' atau pun 'bos' para anggota DPR. Peresmian pergantian anggota DPR oleh Presiden juga harus dilihat sebagai bersifat protokoler dalam kedudukan Presiden sebagai kepala negara. Presiden sebagai kepala eksekutif tidak dapat ikut campur tangan masalah intern DPR. Dengan demikian, menurut hukum, meskipun pelaksanaan Penggantian Antar Waktu (PAW) anggota DPR dan peresmiannya dilakukan oleh Presiden, kedua tata cara prosedural tersebut adalah formalitas belaka. ${ }^{30}$

Di dalam Pasal 215 ditegaskan: ${ }^{31}$ (1). Pemberhentian anggota DPR sebagaimana dimaksud dalam Pasal 213 ayat (2) huruf a, huruf b, huruf d, huruf f, dan huruf $g$, dilakukan setelah adanya hasil penyelidikan dan verifikasi yang dituangkan dalam keputusan Badan Kehormatan DPR atas pengaduan dari pimpinan DPR, masyarakat, dan/atau pemilih. (2) Keputusan Badan Kehormatan DPR mengenai pemberhentian anggota DPR sebagaimana dimaksud pada ayat (1) dilaporkan oleh Badan Kehormatan kepada rapat paripurna. (3) Paling lama 7 (tujuh) hari sejak keputusan Badan Kehormatan DPR yang telah dilaporkan dalam rapat paripurna sebagaimana dimaksud pada ayat (2), pimpinan DPR menyampaikan keputusan Badan Kehormatan DPR kepada pimpinan partai politik yang bersangkutan. (4) Pimpinan partai politik yang bersangkutan menyampaikan keputusan tentang pemberhentian anggotanya kepada pimpinan DPR, paling lambat 30 (tiga puluh) hari sejak diterimanya keputusan Badan Kehormatan DPR sebagaimana dimaksud pada ayat (2) dari pimpinan DPR. (5) Dalam hal pimpinan partai politik sebagaimana dimaksud pada ayat (3) tidak memberikan keputusan pemberhentian sebagaimana dimaksud pada ayat (4), pimpinan DPR meneruskan keputusan Badan Kehormatan DPR sebagaimana

${ }^{30}$ Yusril Ihza Mahendra, Dinamika Tatanegara Indonesia, (Jakarta: Gema Insani Press, 1996), h. 151.

${ }^{31}$ Lihat Pasal 215 UU No. 27 Tahun 2007 tentang MPR, DPR, DPD dan DPR.

Fakultas Syariah dan Hukum UIN Syarif Hidayatullah Jakarta - 205 


\section{Rida Farida}

dimaksud pada ayat (2) kepada Presiden untuk memperoleh peresmian pemberhentian. (6) Presiden meresmikan pemberhentian sebagaimana dimaksud pada ayat (5) paling lama 14 (empat belas) hari sejak diterimanya keputusan Badan Kehormatan DPR atau keputusan pimpinan partai politik tentang pemberhentian anggotanya dari pimpinan DPR.

Kewenangan Penggantian Antar Waktu (PAW) juga disinggung dalam Undang-Undang Nomor 31 Tahun 2002 tentang Partai Politik. Bahkan siapa yang berwenang ditegaskan dalam pasal ini, yaitu partai politik. Pasal 8 menyebutkan bahwa partai politik berhak mengusulkan penggantian antar waktu anggotanya di lembaga perwakilan rakyat sesuai dengan peraturan perundang-undangan. Dinamika politik yang terus berkembang dalam lembaga-lembaga politik di Indonesia merupakan proses alamiah (natural process) yang senantiasa muncul di era reformasi. Begitu pula halnya dengan Penggantian Antar Waktu (PAW), khususnya di lembaga legislatif adalah sesuatu yang wajar terjadi pada negara demokrasi. ${ }^{32}$

Namun demikian, persoalan Penggantian Antar Waktu (PAW) seorang anggota DPR menjadi urusan partai politik masing-masing. Proses tetap dimulai dari partai politik yang bersangkutan sebagai calon legislatif, hal ini tak bisa dipungkiri kalaupun Penggantian Antar Waktu (PAW) tersebut ada desakan dari masyarakat dan tidak serta merta langsung dapat digantikan tanpa melalui proses dan aturan yang telah ditetapkan. Selain itu, mekanisme PAW juga diatur dalam Keputusan Mendagri yang tertuang dalam SK No.161.74-55/2008 tanggal 8 Februari Tahun 2008 tentang Peresmian Pemberhentian dan Pengangkatan Penggantian Antar Waktu (PAW).

\section{Penggantian Antar Waktu (PAW) dalam Putusan Mahkamah Konstitusi}

Anggota DPR merupakan 'wakil rakyat' ataukah 'wakil oranisasi sosial politik'? pertanyaan inilah yang seringkali muncul manakala terjadi Penggantian Antar Waktu (PAW) terhadap anggota DPR. Hubungan antara wakil dengan yang diwakili menurut Gilbert Abcarian ada empat macam, yaitu: ${ }^{33}$ a). Si wakil bertindak sebagai 'wali' (trustee). Wakil bebas bertindak mengambil keputusan menurut pertimbangannya sendiri tapa perlu berkonsultasi dahulu dengan yang diwakilinya. b). Wakil bertindak sebagai 'utusan' (delegate). Wakil bertindak sebagai utusan atau duta dari yang diwakilinya. Wakil selalu mengikuti instruksi dan petunjuk dari yang diwakilinya dalam melaksanakan tugas. c). Wakil bertindak sebagai 'politico'. Wakil kadang-kadang bertindak sebagai wakil dan ada kalanya bertindak sebagai utusan. Tindakan ini bergantung dari isi (materi) yang akan dibahas. d). Wakil bertindak sebagai 'partisan'. Wakil bertindak sesuai dengan keinginan atau program partainya. Setelah wakil dipilih oleh pemilihnya

\footnotetext{
32 FORMAPPI, Lembaga Perwakilan Rakyat di Indonesia, (Jakarta: FORMAPPI, 2005), h. 90.

33 Bintan R. Siragih, Lembaga Perwakilan dan Pemilihan Umum di Indonesia, (Jakarta: Gaya Media Pratama, 1988), h. 85.
} 
maka lepaslah hubungan terjalin dengan parpol yang mencalonkan dalam pemilihan tersebut.

Menurut A. Hoogerwer, hubungan antara si wakil dengan yang diwakilinya ada lima model, yaitu: ${ }^{34}$ a). Model delegate (utusan). Di sini si wakil bertindak sebagai yang diperintah seorang kuasa usaha yang harus menjalankan perintah dari yang diwakilinya. b). Model trustee (wali). Di sini si wakil bertindak sebagai orang yang diberi kuasa, yang memperoleh kuasa penuh dari yang diwakilinya. Jadi ia dapat bertindak berdasarkan pendirian sendiri. c). Model politicos. Di sini wakil kadang-kadang bertindak sebagai delegasi dan kadangkadang bertindak sebagai kuasa penuh. d). Model kesatuan. Di sini anggota parlemen dapat dilihat sebagai wakil seluruh rakyat. e). Model verifikasi (pergolongan). Anggota parlemen dilihat sebagai wakil dari kelompok territorial, sosial atau politik tertentu.

Dari teori Abracarian dan Hoogerwer di atas jika dikontekskan dengan fenomena hubungan antara wakil rakyat dengan partai politiknya di Indonesia, terlihat bahwa hubugannya adalah 'partisan' karena wakil rakyat berindak sesuai dengan keinginan atau program dari organisasi sosial politik yang mengusungnya, bukan sebagai 'wali' (trustee) ataupun 'utusan' (delegate). Setelah wakil rakyat dipilih oleh pemilihnya maka lepaslah hubungan dengan pemilihnya tersebut dan mulailah hubungan dengan partai politik yang mencalonkannya dalam pemilihan umum. Hubungan 'partisan' tersebut akan terbelenggu bagi wakil rakyat yang benar-benar ingin menyuarakan aspirasi rakyat yang diwakilinya manakala hal itu bersebrangan dengan kebijakan partai politiknya.

Dalam pertimbangan Mahkamah Konstitusi menyatakan, dalam sistem pemilihan di mana pemilih langsung memilih nama seseorang sebagai wakil, maka adalah logis jika Penggantian Antar Waktu (PAW) dilakukan oleh pemilih, misalnya melalui mekanisme petisi. Sedangkan dalam sistem pemilihan anggota DPR, maka logis pula apabila Penggantian Antar Waktu (PAW) dilakukan oleh partai yang mencalonkannya. 35 Dalam Putusan Nomor 22-24/PUU-VI/2008, Mahkamah Konstitusi satu penilaian dan pendapat hukum, sebagai berikut. Pasal 1 ayat (2) UUD 1945 menyatakan bahwa kedaulatan berada di tangan rakyat dan dilaksanakan menurut Undang-Undang Dasar. Hal ini menunjukkan bahwa kedaulatan tertinggi berada di tangan rakyat, sehingga dalam berbagai kegiatan pemilihan umum, rakyat langsung memilih siapa yang dikehendakinya. Besarnya suara pilihan rakyat menunjukkan tingginya legitimasi politik yang diperoleh oleh para calon legislatif maupun eksekutif, sebaliknya rendahnya perolehan suara juga menunjukkan rendahnya legitimasi politik calon yang bersangkutan.

Seharusnya pasca Putusan Nomor 22-24/PUU-VI/2008, kedudukan anggota DPR semakin kuat karena mewakili rakyat yang dibuktikan melalui besarnya suara pilihan rakyat yang menunjukkan tingginya legitimasi politik yang

34 Bintan R. Siragih, Lembaga Perwakilan dan Pemilihan Umum di Indonesia, (Jakarta: Gaya Media Pratama, 1988), h. 85-86.

35Putusan Mahkamah Konstitusi RI No. 008/PUU-IV/2008 tentang Pengujian UU No. 10 Tahun 2008 tentang Pemilu Anggota DPR, DPD dan DPRD. 


\section{Rida Farida}

diperoleh oleh para calon legislatif. Dengan demikian, anggota DPR yang dicalonkan oleh partai politik akan menjadi wakil rakyat yang konkret karena mewakili konstituen-konstituen tertentu. Peran partai dalam proses rekrutmen telah selesai dengan dipilihnya calon-calon yang cakap untuk kepentingan rakyat, karena rakyat tidak mungkin secara keseluruhan mengartikulasikan syarat-syarat calon pemimpin yang dipandang sesuai dengan keinginan rakyat kecuali melalui organisasi politik yang memperjuangkan hak-hak dan kepentingan politik dari kelompok-kelompok dalam masyarakat. Karena itu, keterampilan calon anggota legislatif tidak boleh bergeser dari keputusan rakyat yang berdaulat kepada keputusan pengurus partai politik.

Untuk itu, meskipun UUD 1945 (sesudah perubahan) seolah-olah member kesan terlalu mengistimewakan partai politik, tidak berarti bahwa partai politik boleh menegasikan atas kedaulatan rakyat sebagai asas fundamental sistem ketatanegaraan Indonesia. Harus dipahami bahwa hal itu lebih disebabkan karena pada masa lalu (masa Orde Baru) peran partai politik telah didegradasikan oleh negara dan kedaulatan rakyat bergeser menjadi kedaulatan negate/kedaulatan penguasa negara.

Oleh karena itu, seharusnya pergeseranya bukan pergeseran dari kedaulatan negara/pemerintah ke kedaulatan parpol, melainkan harus dikembalikan ke arah kedaulatan rakyat. Sebagai konsekuensinya, pemberhentian anggota DPR yang dimaksud oleh Pasal 22B UUD 1945 pengaturan dalam Undang-Undang atau kode etik perilaku sebagai wakil rakyat, tak perlu karena Penggantian Antar Waktu (PAW) oleh partai politik induknya. Penggantian Antar Waktu (PAW) oleh partai politik atas anggotanya yang duduk di lembaga perwakilan dengan alasan pelanggaran AD/ART (Pasal 12 huruf b UU Parpol) tidak menjamin prinsip due process of law yang merupakan salah satu prinsip negara hukum, karena bisa bersifat subjektif pimpinan partai politik yang sulit dikontrol oleh publik. Yang masih bersifat objektif dan dapat diterima ialah Penggantian Antar Waktu (PAW) atas dasar alasan mengundurkan diri dari parpol atau masuk parpol lain, atau melanggar peraturan perundang-undangan. ${ }^{36}$

Menarik juga disimak pertimbangan Mahkamah Konstitusi dalam penolakan permohonan Lily C. Wahid, antara lain menyatakan bahwa Mahkamah Konstitusi pernah memutus (vide Putusan Nomor 008/PUU-IV/ 2006, bertanggal 28 September 2006), bahwa Penggantian Antar Waktu (PAW) karena pencabutan keanggotaan dari partai politik bagi anggota DPR itu sah dan konstitusional sebagai hak partai politik. Pertimbangannya antara lain, karena menurut Pasal 22E ayat (3) UUD 1945, peserta Pemilu untuk anggota DPR itu adalah partai politik. Oleh karena peserta Pemilu untuk anggota DPR adalah partai politik dan tak seorang pun dapat menjadi anggota DPR tanpa melalui partai politik maka menjadi wajar dan proporsional jika partai politik diberi wewenang untuk melakukan PAW atas anggotanya yang bertugas di DPR. Selain itu dalam kegiatan politik sehari-hari (day to day politics) ketentuan tentang kewenangan PAW bagi partai politik ini memanga dilematis.

\footnotetext{
${ }^{36}$ Lihat Dissenting Opinion Abdul Mukhtie Fadjar dalam Putusan MK RI No. 008/PUU-IV/2006.
} 
Berdasarkan pengalaman sejarah ketika partai politik diberi kewenangan melakukan PAW maka kewenangan tersebut dapat digunakan oleh pimpinan partai politik untuk membungkam anggota DPR sehingga tugasnya sebagai pengemban aspirasi rakyat menjadi tumpul dan tidak efektif karena ancaman PAW, sebaliknya berdasarkan pengalaman sejarah pula ketika partai politik tidak diberi kewenangan untuk melakukan PAW, banyak anggota DPR yang melakukan pelanggaran, baik hukum maupun etika, tanpa bisa ditindak secara langsung oleh partai politik yang bersangkutan sehingga yang bersangkutan bisa merusak citra, bukan hanya partai politik yang bersangkutan melainkan juga citra DPR di mana yang bersangkutan bertugas sebagai wakil rakyat. ${ }^{37}$ Berdasarkan hal tersebut maka Mahkamah Konstitusi tetap pada pendiriannya bahwa partai politik berwenang melakukan PAW bagi anggotanya yang bertugas sebagai anggota DPR berdasarkan ketentuan-ketentuan yang diatur dalam Undang-Undang (vide Pasal 22 B UUD 1945) maupun yang diatur dalam AD/ART partai politik yang bersangkutan.

Seorang warga negara yang memilih dan bergabung dalam partai politik tertentu dengan sendirinya secara sukarela menundukkan diri, terikat dan menyetujui AD/ART partai politik yang bersangkutan. Setiap anggota DPR yang mewakili partai politik harus memiliki integritas yang baik pula, dan pada gilirannya harus memberikan pertanggungjawaban (akuntabilitas) sampai sejauh mana komitmen dan kinerjanya. Anggota DPR dicalonkan oleh partai politik tertentu, dengan demikian merupakan representasi partai politik di DPR. Dalam rangka menegakkan otoritas dan integritas partai politik, maka partai politik dapat mengusulkan kepada pimpinan DPR untuk memberhentikan dan melakukan PAW terhadap anggota partai politik yang menjadi anggota DPR, karena dianggap melanggar AD/ART. Jika partai politik tidak diberi wewenang untuk menjatuhkan sanksi (tindakan) terhadap anggotanya yang menyimpang dari AD/ART dan kebijaksanaan partai, maka anggota partai bebas untuk berbuat semena-mena.

Meskipun partai politik berwenang melakukan PAW bagi anggotanya yang bertugas sebagai anggota DPR namun di dalam pelaksanaannya haruslah sesuai dengan ketentuan Undang-Undang (vide Pasal 22B UUD 1945) dan AD/ART partai politik yang bersangkutan, sehingga tidak boleh dilakukan dengan sewenang-wenang atau dengan cara melanggar hukum. Jika hal itu dilakukan maka anggota partai politik yang bersangkutan dapat melakukan upaya hukum, baik melalui peradilan tata usaha negara maupun melalui peradilan umum.

Argumentasi Mahkamah Konstitusi yang menolak permohonan Lily C. Wahid dalam perkara Nomor 38/PUU-VIII/2010 tentang Pengujian UndangUndang Nomor 27 Tahun 2009 tentang MPR, DPR, DPD dan DPRD dan UndangUndang Nomor 2 Tahun 2008 tentang Partai Politik, yang mendasar pada Putusan MK Nomor 008/PUU-IV/2006, bertanggal 28 September 2006, tidak sepenuhnya

37 Putusan MK RI No. 38/PUU-VII/2010 tentang Pengujian UU No. 27 Tahun 2009 tentang MPR, DPR, DPD dan DPRD dan UU No. 2 Tahun 2008 tentang Partai Politik. 


\section{Rida Farida}

tepat karena Pemilu 2009 adalah dengan sistem Pemilu proporsional terbuka dengan penerapan suara terbanyak dan Pemohon memperoleh dukungan suara terbanyak sehingga oleh Komisi Pemilihan Umum ditetapkan sebagai anggota DPR terpilih, dan terpilihnya Pemohon menempatkan kedaulatan benar-benar berada di tangan rakyat sesuai dengan Pasal 1 ayat (2) UUD 1945. Sementara Pemilu tahun 2004 mendasarkan pada sistem Pemilu proporsional terbuka dengan penerapan daftra nomor urut, sehingga kedaulatan berada di tangan partai politik. Dengan hadirnya Undang-Undang Nomor 27 Tahun 2009 tentang MPR, DPR, DPD dan DPRD yang menentukan sistem Pemilu proporsional terbuka yang kemudian dikoreksi oleh Mahkamah Konstitusi melalui Putusan MK Nomor 2224/PUU-IV/2008 menjadi sistem proporsional terbuka dengan suara terbanyak, seharusnya hak Penggantian Antar Waktu (PAW) terhadap anggota parleman tidak sepenuhnya berada di tangan partai politik, tetapi konstituen juga memiliki hak untuk menentukan apakah anggota partai politik tersebut layak di-PAW ataukah tidak. Hegemoni partai politik dalam masalah Penggantian Antar Waktu (PAW) anggota partai politik seharusnya tidak mutlak. Partai politik perlu mempertimbangkan aspirasi konstituen yang telah memilihnya.

\section{Hak Penggantian Antar Waktu (PAW) oleh Partai Politik}

Banyaknya partai politik bukanlah pengalaman baru bagi sejarah politik di Indonesia. Sejak masa perjuangan pra-kemerdekaan, pasca kemerdekaan sampai pemilu 1955 jumlah partai politik tidak sedikit. Pada era Orde Baru, jumlah partai politik dibatasi, namun pasca reformasi partai-partai kembali bermunculan. ${ }^{38}$ Partai politik yang menjadi pilar demokrasi tidak sekedar harus ada, melainkan juga kuat dan berakar pada legitimasi sosial. Partai politik harus benar-benar menjadi wadah penampung aspirasi masyarakat. Sistem demokrasi modern memang bertumpu pada sistem perwakilan yang terpresentasikan dalam partai politik. ${ }^{39}$

Fungsi yang lain dari partai politik adalah menciptakan mekanisme artikulasi kepentingan masyarakat, agar kepentingan-kepentingan tersebut dapat diakomodir secara luas oleh pemerintah yang pada gilirannya akan menjadi pola yang sinergis antara pemerintah dengan masyarakat. Dengan demikian diharapkan partai politik mempunyai rasa tanggung jawab yang tinggi kepada para pemilihnya, oleh karenanya harus menyesuaikan dengan keinginan serta kebutuhan masyarakat. Bahkan harus rela berkorban demi kepentingan pendukungnya. ${ }^{40}$ Walaupun demikian, dalam perjalanannya seorang anggota dewan dapat diberhentikan oleh partai yang menjadi induknya dengan alasan tertentu sesuai Undang-Undang meskipun keberadaan anggota dewan tersebut merupakan representasi dari rakyat. Hal ini sesuai dengan Pasal 213 ayat (2) huruf e UU Susduk menyatakan bahwa, "Anggota DPR berhenti Antar Waktu karena: e.

\footnotetext{
38 Sebastian Salang, Potret Partai Politik di Indonesia, (Jakarta: Forum Politisi, 2007), h.21

${ }^{39}$ Firman Subagyo, Menata Partai Politik dalam Arus Demokratisasi Indonesia, (Jakarta: Wahana Semesta Intermedia), h.6

${ }^{40}$ Miriam Budiardjo, Dasar-dasar Ilmu Politik, (Jakarta: Gramedia Pustaka, 2000), h.21
}

210 - Jurnal Cita Hukum. Vol. I No. 2 Desember 2013. 
diusulkan oleh partai politiknya sesuai dengan peraturan perundang-undangan." Sedangkan Pasal 12 huruf b UU Parpol menyatakan bahwa, "Anggota partai politik yang menjadi anggota lembaga perwakilan rakyat dapat diberhentikan keanggotaannya dari lembaga perwakilan rakyat apabila: $b$. diberhentikan dari keanggotaan partai politik yang bersangkutan karena melanggar anggaran dasar dan anggaran rumah tangga."

Sehubungan dengan hal tersebut di atas, mekanisme Penggantian Antar Waktu (PAW) menjadi hak prerogatif partai politik. Sehingga memungkinkan seorang anggota parlemen yang merupakan wakil (representation) rakyat yang dipilih melalui mekanisme demokratis yaitu pemilihan umum yang berdasarkan kekuasaan atau kedaulatan rakyat dapat diberhentikan oleh partai politiknya.

Keberadaan seorang anggota partai politik di parlemen merupakan pelaksanaan kedaulatan rakyat sebagai wujud pelaksanaan demokrasi tidak langsung atau demokrasi perwakilan karena keberadaan parlemen sebagai perlembagaan kedaulatan rakyat. Eksistensi seorang anggota parlemen khususnya anggota Dewan Perwakilan Rakyat yang berada dalam lembaga perwakilan rakyat.

\section{Mekanisme Penggantian Antar Waktu (PAW) Anggota DPR}

Seperti yang telah disebutkan sebelumnya, bahwasanya peraturan mengenai Penggantian Antar Waktu (PAW) diatur dalam Undang-Undang Nomor 27 Tahun 2009 tentang MPR, DPR, DPD dan DPRD. Penggantian Antar Waktu (PAW) terdiri dari dua kategori, yaitu: ${ }^{41}$ Penggantian Antar Waktu (PAW) Tetap, dan pergantian Antar Waktu sementara.

Ada beberapa tahapan Penggantian Antar Waktu (PAW) Tetap, yaitu; Pertama, Tahapan Pengajuan. Pemberhentian anggota DPR dengan alasan meninggal dunia, mengundurkan diri, dinyatakan bersalah berdasarkan putusan pengadilan yang telah memperoleh kekuatan hukum tetap karena melakukan tindak pidana yang diancam dengan pidana penjara 5 (lima) tahun atau lebih, diusulkan oleh partai politiknya sesuai dengan peraturan perundang-undangan, diberhentikan sebagai anggota partai politik sesuai dengan ketentuan peraturan perundang-undangan, dan menjadi anggota partai politik lain diusulkan oleh pimpinan partai politik kepada pimpinan DPR dengan tembusan kepada Presiden. Tujuh hari sejak diterimanya usulan pemberhentian, pimpinan DPR akan menyampaikan usulan tersebut kepada Presiden untuk memperoleh peresmian pemberhentian. Jika disetujui, Presiden akan meresmikannya paling lama 14 (empat belas) hari sejak diterimanya usul pemberhentian anggota DPR dari pimpinan DPR.

Tahapan, Penyelidikan dan Verifikasi. Pemberhentian Anggota DPR dengan alasan tidak dapat melaksanakan tugas secara berkelanjutan atau berhalangan tetap sebagai anggota DPR selama 3 (tiga) bulan berturut-turut tanpa keterangan apa pun, melanggar sumpah/janji jabatan dan kode etik DPR, tidak menghadiri rapat paripurna dan/atau rapat alat kelengkapan DPR yang menjadi

\footnotetext{
${ }^{41}$ Lihat Undang-Undang Nomor 27 Tahun 2009 tentang MPR, DPR, DPD dan DPRD.
} 


\section{Rida Farida}

tugas dan kewajibannya sebanyak 6 (enam) kali berturut-turut tanpa alasan yang sah, tidak lagi memenuhi syarat sebagai calon anggota DPR sesuai dengan ketentuan peraturan perundang-undangan mengenai pemilihan umum anggota DPR, DPD, dan DPRD, melanggar ketentuan larangan sebagaimana diatur dalam Undang-Undang, dilakukan setelah adanya hasil penyelidikan dan verifikasi yang dituangkan dalam keputusan Badan Kehormatan DPR atas pengaduan dari pimpinan DPR, masyarakat, dan/atau pemilih. Selanjutnya, Keputusan Badan Kehormatan DPR mengenai pemberhentian anggota DPR dilaporkan oleh Badan Kehormatan kepada rapat paripurna. Paling lama 7 (tujuh) hari sejak keputusan Badan Kehormatan DPR yang telah dilaporkan dalam rapat paripurna, pimpinan DPR menyampaikan keputusan Badan Kehormatan DPR kepada pimpinan partai politik yang bersangkutan.

Pimpinan partai politik yang bersangkutan menyampaikan keputusan tentang pemberhentian anggotanya kepada pimpinan DPR, paling lambat 30 (tiga puluh) hari sejak diterimanya keputusan Badan Kehormatan DPR sebagaimana dimaksud pada ayat (2) dari pimpinan DPR. Pimpinan partai politik tidak memberikan keputusan pemberhentian, pimpinan DPR meneruskan keputusan Badan Kehormatan DPR kepada Presiden untuk memperoleh peresmian pemberhentian. Kemudian Presiden meresmikan pemberhentian paling lama 14 (empat belas) hari sejak diterimanya keputusan Badan Kehormatan DPR atau keputusan pimpinan partai politik tentang pemberhentian anggotanya dari pimpinan DPR.

Ketiga, Pelaksanaan Penyelidikan dan Verifikasi. Pelaksanaan penyelidikan dan verifikasi, Badan Kehormatan DPR dapat meminta bantuan dari ahli independen. Ketentuan lebih lanjut mengenai tata cara penyelidikan, verifikasi, dan pengambilan keputusan oleh Badan Kehormatan DPR diatur dengan peraturan DPR tentang tata beracara Badan Kehormatan.

Keempat, Reposisi Anggota DPR Pasca Penggantian Antar Waktu (PAW). Adapun ketentuan Penggantian Antar Waktu (PAW) yaitu anggota DPR yang berhenti Antar Waktu digantikan oleh calon anggota DPR yang memperoleh suara terbanyak urutan berikutnya dalam daftar peringkat perolehan suara dari partai politik yang sama pada daerah pemilihan yang sama. Calon anggota DPR yang memperoleh suara terbanyak urutan berikutnya (meninggal dunia, mengundurkan diri, atau tidak lagi memenuhi syarat sebagai calon anggota DPR), anggota DPR digantikan oleh calon anggota DPR yang memperoleh suara terbanyak urutan berikutnya dari partai politik yang sama pada daerah pemilihan yang sama. Sedang ketentuan masa jabatan anggota DPR pengganti Antar Waktu melanjutkan sisa masa jabatan anggota DPR yang digantikannya.

Kelima, Penyampaian Penggantian Antar Waktu (PAW) Anggota DPR. Pimpinan DPR menyampaikan nama anggota DPR yang diberhentikan Antar Waktu dan meminta nama calon pengganti Antar Waktu kepada KPU, kemudian KPU menyampaikan nama calon pengganti Antar Waktu kepada pimpinan DPR paling lambat 5 (lima) hari sejak diterimanya surat pimpinan DPR. Paling lambat 7 (tujuh) hari sejak menerima nama calon pengganti Antar Waktu dari KPU, 
Pimpinan DPR menyampaikan nama anggota DPR yang diberhentikan dan nama calon pengganti Antar Waktu kepada Presiden dan Paling lambat 14 (empat belas) hari sejak menerima nama anggota DPR yang diberhentikan dan nama calon pengganti Antar Waktu dari pimpinan DPR, Presiden meresmikan pemberhentian dan pengangkatannya dengan keputusan Presiden. Sebelum memangku jabatannya, anggota DPR pengganti Antar Waktu mengucapkan sumpah/janji yang dipandu oleh pimpinan DPR, dengan tata cara dan teks sumpah/janji sebagaimana diatur dalam Pasal 75 dan Pasal 76 Undang-Undang Nomor 27 Tahun 2009 tentang MPR, DPR, DPD dan DPRD. Penggantian Antar Waktu (PAW) anggota DPR tidak dilaksanakan apabila sisa masa jabatan anggota DPR yang digantikan kurang dari 6 (enam) bulan.

\section{Kesimpulan}

Adapun kesimpulan yang dapat diberikan dalam penulisan ini adalah sebagai berikut:

Pertama, Bahwa Penggantian Antar Waktu (PAW) seorang anggota DPR tidak dilaksanakan asal copot, tetapi dilakukan, mengacu pada aturan dan mekanisme hukum yang telah ditetapkan, dalam hal ini Undang-Undang Nomor 27 Tahun 2009 tentang MPR, DPR, DPD dan DPRD. Sedangkan operasional pelaksanaannya dijabarkan dalam Peraturan Dewan Perwakilan Rakyat Republik Indonesia Nomor 1/DPR RI/I/2009-2010 tentang Tata Tertib.

Kedua, Bahwa yang menjadi faktor yang melatarbelakangi terjadinya Penggantian Antar Waktu (PAW) adalah Penggantian Antar Waktu (PAW) menjadi alat efektif untuk menyingkirkan anggota dewan yang berseberangan dengan kepentingan penguasa. Sedangkan sekarang Penggantian Antar Waktu (PAW) menjadi alat efektif untuk menyingkirkan anggota dewan yang berseberangan dengan kepentingan pengurus partai politik. Akibatnya eksistensi anggota dewan sangat tergantung oleh selera pengurus partaipolitik, sehingga menggeser orientasi anggota dewan menjadi penyalur kepentingan pengurus partai politik. Padahal keberadaan anggota dewan karena dipilih oleh rakyat dalam suatu pemilihan umum yang bersifat langsung, bebas, rahasia, jujur dan adil. Bila suatu partai politik mengajukan calon pengganti menurut nomor urut berdasar daerah pemilihan yang kurang jelas dan menimbulkan banyak penafsiran. Ketidakjelasan seperti ini akan menimbulkan konflik internal dalam partai karena sebagian pengurus partai (khususnya tingkat pusat) lebih memilih nomor urut menurut daerah pemilihan, sedangkan sebagian lagi (khususnya tingkat daerah) cenderung memilih nomor urut menurut wilayah yang diwakili.

Ketiga, Bahwa sebagai negara demokrasi, tentunya membenarkan keberadaan Partai Politik sebagai pilar dari demokrasi atau pelaksanaan kedaulatan rakyat itu. Hal ini didasari pada pelaksanaan demokrasi tidak langsung yang dilaksanakan melalui pemilihan umum untuk membentuk dan tentunya keberadaan partai politik sebagai peserta pemilihan umum. Partai politik pada pokoknya memiliki kedudukan (status) dan peranan (role) yang sentral dan 


\section{Rida Farida}

penting dalam setiap sistem demokrasi karena memainkan peran yang penting sebagai penghubung antara pemerintahan negara dengan warga negaranya.

Keempat, Ada banyak alasan bagi partai politik untuk mengusulkan Penggantian Antar Waktu (PAW) terhadap anggotanya yang duduk di lembaga legislatif. Tetapi pada umumnya dalam literature disebutkan bahwa Penggantian Antar Waktu (PAW) ditujukan kepada anggota parpol yang tidak menunjukkan loyalitas kepada Dewan Pimpinan Pusat (DPP).

\section{Pustaka Acuan}

Asshiddiqie, Jimly, Hukum Tata Negara dan Pilar-pilar Demokrasi, (Jakarta: Konstitusi Press, 2005)

Budiardjo, Miriam, Dasar-dasar Ilmu Politik, (Jakarta: Gramedia Pustaka Utama, 1992)

FORMAPPI, Lembaga Perwakilan Rakyat di Indonesia, (Jakarta: FORMAPPI, 2005)

Huda, Ni'matul, Hukum Tata Negara Indonesia, (Jakarta: RajaGrafindo Persada, 2006)

Kusuma, B. Ananda, Jurnal Konstitusi Volume 3 Nomor 4 Tentang Recall, (Jakarta: MK RI, 2006)

Mahfud MD, Politik Hukum Di Indonesia, (Jakarta: Rajawali Pers, 2009)

Mh. Isnaeni, MPR-DPR sebagai Wahana Mewujudkan Demokrasi Pancasila, (Jakarta: Yayasan Idayu, 1982)

Moh. Mahfud MD, Perkembangan Politik Hukum, Studi tentang Pengaruh Konfigurasi Politik terhadap Produk Hukum di Indonesia, (Yogyakarta: FH UGM Press, 1993)

Munandar, Haris, Pembangunan Politik, Situasi Global dan Hak Asasi Manusia, (Jakarta: Gramedia, 1994)

Mahendra, Ihza, Yusril, Dinamika Tatanegara Indonesia, (Jakarta: Gema Insani Press, 1996)

Napitupulu, Paimin, Menuju Pemerintahan Perwakilan, (Bandung: Alumni, 2007)

Noer, Deliar, Mohammad Hatta Suatu Biografi Politik, (Jakarta: LP3ES, 1989)

Pamungkas, Bintang Sri Saya Musuh Politik Soeharto, (Jakarta: Pijar Indonesia, 1994)

Salang, Sebastian, Menghindari Jeratan Hukum Bagi Anggota Dewan, (Jakarta: PT. Penebar Swadaya, 2009)

Samega, Indra, Menata Negara, Usulan LIPI tentang RUU Politik, (Bandung: Mizan, 1998)

Sanit, Arbi, Perwakilan Politik Di Indonesia, (Jakarta: Rajawali, 1985)

Yuhana, Abdy, Sistem Ketatanegaraan Indonesia Pasca Perubahan UUD 1945, (Bandung: Fokusmedia, 2009) 
Jurnal Cita Hukum merupakan berkala ilmiah yang diterbitkan oleh Fakultas Syariah dan Hukum Universitas Islam Negeri (UIN) Syarif Hidayatullah Jakarta. Berkala ilmiah ini mengkhususkan diri dalam pengkajian ilmu hukum dan berupaya menyajikan pelbagai hasil riset ilmiah terkini dan bermutu. Seluruh artikel yang dipublikasikan dalam berkala ilmiah ini merupakan pandangan dari para penulisnya dan tidak mewakiliberkala ilmiah dan atau lembaga afiliasi penulisnya.

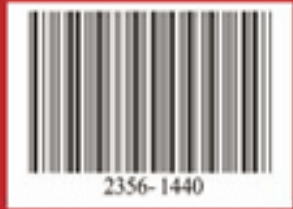

